\title{
Two new species of Goeldichironomus Fittkau from southeast Brazil (Diptera, Chironomidae)
}

\author{
Susana Trivinho-Strixino ${ }^{1} \&$ Giovanni Strixino ${ }^{1}$
}

\begin{abstract}
${ }^{1}$ Depto. de Hidrobiologia. Laboratório de Entomologia Aquática. Universidade Federal de São Carlos, Rodovia Washington Luiz Km 235, São Carlos-SP. Brasil. Caixa Postal 676, CEP: 13565-905. strixino@power.ufscar.br
\end{abstract}

\begin{abstract}
Two new species of Goeldichironomus Fittkau from southeast Brazil (Diptera, Chironomidae). The adult and immature stages of two new species of Goeldichironomus are described and figured. Larvae of G. luridus sp. nov., reared in the laboratory from egg masses, are abundant on organically enriched sediments of a chicken slaughter-house effluent treatment lagoon. Larvae of $G$. petiolicola sp. nov., live inside petioles of aquatic macrophytes such as Eichhornia azurea and Pontederia lanceolata.
\end{abstract}

KEYWORDS. Goeldichironomus; Neotropics, Taxonomy.

RESUMO. Duas novas espécies de Goeldichironomus Fittkau do sudeste do Brasil (Diptera, Chironomidae). Os adultos e os estágios imaturos de duas novas espécies de Goeldichironomus são descritos e ilustrados. As larvas de G. luridus sp. nov., criadas em laboratório para obtenção dos adultos, habitam os sedimentos organicamente enriquecidos de uma lagoa de estabilização de um matadouro de aves. As larvas de G. petiolicola sp. nov., vivem no interior dos pecíolos de macrófitas aquáticas como Eichhornia azurea e Pontederia lanceolata.

PALAVRAS-CHAVE. Goeldichironomus, Região Neotropical, Taxonomia.

Goeldichironomus Fittkau, 1965 is a Neotropical genus with so far nine species in Brazil (Spies \& Reiss, 1996; TrivinhoStrixino \& Strixino, 1998), many of them recorded from the State of São Paulo (Trivinho-Strixino \& Strixino, 1999). The genus has a wide distribution in lentic ecosystems of this State (Roque et al. 2004), where the larvae live both on littoral sandy sediments and in/on aquatic macrophytes. Here we describe the immature stages and adults of two new species.

All the material examined was mounted on slides with Euparal or Hoyer's medium. The morphological terminology follows Sæther (1977, 1980), except for the term 'taeniae' (Langton 1994) used for flattened setae on the pupal abdomen. Measurements are given as the values of the holotype (where applicable) followed by values of the smallest and the largest paratype, respectively.

\section{Goeldichironomus luridus sp. nov.}

Etymology. From Latin luridus, dirty; refers to the habitat of the larvae.

Types. Holotype: male imago, São Carlos, SP, Brazil, 01/VI/ 2004. Paratypes: 2 male imagoes with respective pupal exuviae and 2 male imagoes, 12/VI/2004; 1 female, 1/VI/2004; 2 pupal exuviae, 17/VI/2004; $24^{\text {th }}$ instar larvae, 12/IV/2004; $14^{\text {th }}$ instar larva, $8 / \mathrm{IX} / 2004$. All material stems from laboratory rearings of egg masses collected in a chicken slaughter-house effluent treatment lagoon. The holotype and most paratypes are deposited in the Laboratório de Entomologia Aquática collection, Universidade Federal de São Carlos, SP, Brazil
(UFSCar). One male paratype is deposited in the Museu de Zoologia, USP, SP, Brazil.

Diagnosis. The male hypopygium of Goeldichironomus luridus sp. nov. is similar to those of G. natans Reiss, 1974 and G. fluctuans Reiss, 1974, differing by the shape and orientation of the superior volsella. The female genitalia of G. luridus differ from that of G. amazonicus (Fittkau, 1968) by the number of setae on segment $X$. The pupa of $G$. luridus resembles thouse of G. amazonicus and G. natans in the shape of the anal comb, but differs by the absence of shagreenation on the sternites and on tergites VII and VIII. The $4^{\text {th }}$ instar larva of G. luridus differs from all these species, except $G$. amazonicus, by the design of the mental teeth and by the length of the ventral tubules, which are longer in G. natans and absent or rudimentary in G. fluctuans. The partially consolidated 4th labral sclerite of $G$. luridus larvae matches the condition in $G$. xiborena Reiss, 1974.

\section{Description}

Adult male.

Total length $4.20 \mathrm{~mm}$ (4.00 - 4.25). Color greenish yellow.

Head. Frontal tubercles small, about $6 \mu \mathrm{m}$ long. Antenna $1.16 \mathrm{~mm}$ long $(1.12,1.23) ; \mathrm{AR}=2.64(2.35,2.52)$. . .lpomeres $_{2-5}$ $=28,62,87,125 \mu \mathrm{m}(31,34 ; 62 ; 93,95 ; 137,140)$. Clypeus with 10 setae $(10,12)$.

Thorax setal count: $15-17$ acrostichals, $10-12$ dorsocentrals, 5 prealars, 1 supraalar and 3-4 scutellars.

Wing. Length $1.84 \mathrm{~mm}(1.77,2.06)$, membrane transparent, without setae. $\mathrm{R}, \mathrm{R}_{1}$ and $\mathrm{R}_{4+5}$ setose. $\mathrm{VR}=1.23(1.18,1.22)$. Squama with 7-9 long setae. 
Leg segment lengths in $\mu \mathrm{m}$ and LR:

\begin{tabular}{lllll}
\hline & $\mathrm{Fe}$ & $\mathrm{Ti}$ & $\mathrm{Ta}_{1}$ & $\mathrm{Ta}_{2}$ \\
\hline $\mathrm{I}$ & 815 & 662 & 954 & 477 \\
& 765,892 & 661,708 & 953,1092 & 461,538 \\
II & 754 & 692 & 369 & 215 \\
& 754,861 & 692,815 & 369,477 & 215,277 \\
III & 846 & 954 & 600 & 338 \\
& 846,985 & 923,1108 & 615,708 & 369,415 \\
\hline & $\mathrm{Ta}_{3}$ & $\mathrm{Ta}_{4}$ & $\mathrm{Ta}_{5}$ & $\mathrm{LR}$ \\
\hline & 415 & 292 & 169 & 1.44 \\
& 446 & 307,354 & 169,200 & $1.44,1.54$ \\
& 185 & 138 & 92 & 0.53 \\
& 200 & 108,154 & 92,108 & $0.53,0.58$ \\
& 292 & 185 & 108 & 0.63 \\
& 278,338 & 185,231 & 108,123 & $0.67,0.64$ \\
\hline
\end{tabular}

Hypopygium (Fig. 1). Anal point slender with apex slightly bent to ventral. Superior volsella bent at 90 degrees, distal part orientated obliquely toward median, paralleling posterior margin of anal tergite; basal section short and microtrichiacovered. Inferior volsella more or less parallel-sided and not clubbed apically, bearing 14-15 long setae. Gonostylus narrowed at apex.

Adult female. Total length $4.0 \mathrm{~mm}$. Coloration as male.

Head. Frontal tubercles small, about $7 \mu \mathrm{m}$ long. Antennal flagellomeres $_{1-5}=112,71,77,84,152 \mu \mathrm{m}$. AR $=0.29$. Palpomeres ${ }_{2-5}=28,77,91,143 \mu \mathrm{m}$. Clypeus with 17 setae.

Thoracic setal count: 17 acrostichals, 22 dorsocentrals, 5 prealars, 1 supraalar, 6 scutellars.

Wing. Length $2.03 \mathrm{~mm}$, width $0.68 \mathrm{~mm}$. VR $=1.23$.

Leg segment lengths in $\mu \mathrm{m}$ and LR:

\begin{tabular}{lllllllll}
\hline & $\mathrm{Fe}$ & $\mathrm{Ti}$ & $\mathrm{Ta}_{1}$ & $\mathrm{Ta}_{2}$ & $\mathrm{Ta}_{3}$ & $\mathrm{Ta}_{4}$ & $\mathrm{Ta}_{5}$ & $\mathrm{LR}$ \\
\hline I & 754 & 600 & 938 & 431 & 369 & 292 & 154 & 1.56 \\
II & 692 & 708 & 385 & 185 & 154 & 123 & 61 & 0.54 \\
III & 846 & 954 & 554 & 323 & 277 & 169 & 123 & 0.58 \\
\hline
\end{tabular}

Genitalia. Sternite VIII bearing more than 40 irregularly distributed setae on each side. Seminal capsule ovoid, about $120 \mu \mathrm{m}$ long, with short neck. Spermathecal duct straight. Gc IX without setae. Segment X with 5-6 setae on each side. Postgenital plate relatively large, triangular.

Pupa

Exuviae grayish. Abdomen length 3.25-3.75 mm. Cephalic tubercles small, conical and apically pointed; frontal setae inserted subapically (Fig. 2). Hook row $340 \mu \mathrm{m}$ about $3 / 4$ width of segment II. Pedes spurii B present on segment II. Pedes spurii A present on sternite IV. Patches of small spines in the posterolateral corners of paratergites V-VII small and inconspicuous. Sternites bare. Tergite I without shagreen; IIVI extensively covered with shagreenation; VII and VIII bare. Segment VIII with posterolateral yellowish brown anal comb of 4-5 marginal teeth and many short additional overlapping ventral teeth (Fig. 3). Anal lobe with complete fringe of ca 6065 taeniae and 1 dorsal taenia on each side. Abdominal setation: segments I - IV $=1$, 3, 3, 3 L setae; V- VIII $=4$, 4, 4, 5 lateral taeniae.

$4^{\text {th }}$ instar larva.

Total length $6.1-7.6 \mathrm{~mm}$. Color reddish; head white with dark brown ventral occipital margin and triangulum occipitale. Head: width $469 \mu \mathrm{m}$, length $627 \mu \mathrm{m}$. Labral sclerites 3 and 4 present; 4 partially consolidated (fig. 4). Premandible with 2 teeth. Pecten epipharyngis simple, with 14-15 unequal teeth (fig. 5). Antennal segment lengths $=81,25,20,16,6 \mu \mathrm{m}$; $\mathrm{AR}=$ 1.21. Mandible about $200 \mu \mathrm{m}$ long, teeth and seta subdentalis as in Fittkau (1968). Mentum (fig. 6) with slightly notched median and 6 pairs of dark lateral teeth.

Abdomen (Fig. 7) with two pairs of short ventral tubules on $8^{\text {th }}$ segment, measuring about $200 \mu \mathrm{m}$. Anal tubules short, about $250 \mu \mathrm{m}$.

\section{Ecological Notes}

The egg masses of G. luridus were collected on the shore of a chicken slaughter-house effluent treatment lagoon. They were maintained in a Petri dish with distilled water until the eclosion of the larvulae that were reared in the laboratory using the technique described by Strixino \& Strixino (1982) to obtain the pupae and adults.

According to Epler (2001) different species of the genus Goeldichironomus are common and abundant on organically enriched sediments of shallow lentic waters, including waste stabilization lagoons. In these systems the organic material is altered by bacterial action and photosynthesis. The detritus resulting from this process accumulates at the bottom, creating a soft layer of organic sediment, which provides food and substrate for chironomid larvae (Grodhaus, 1967). In the lagoon where we obtained the G. luridus egg masses there were also many larvae of G. holoprasinus and G. fluctuans, and others such as Chironomus sancticaroli Strixino \& Strixino, 1981.

\section{Goeldichironomus petiolicola sp. nov.}

Etymology. From Latin, petiolus + - cola $=$ petioleinhabiting; refers to the microhabitat of the larvae inside the petioles of aquatic macrophytes.

Types. Holotype: male imago, São Carlos, SP, Brazil, campus UFSCar, Leg. F. Roque, 07/IX/1999. Paratypes: 2 male imagoes; one with pupal exuviae, Luiz Antônio, SP, Lagoa do Diogo, E. E. de Jataí, Leg. L. C. Correia, 25/VII/2001; 1 male imago, Luiz Antônio, SP, Lagoa do Óleo, E. E. de Jataí. Leg. S. T. Strixino, 07/V/2003; 1 male imago and 14th instar larva, in the same slide, Luiz Antônio, SP, Lagoa do Óleo, E. E. de Jataí. Leg. S. T. Strixino, 05/VIII/2003; 1 male imago, Manaus, AM, Igarapé Cururu, Leg. S. Couceiro, 26/III/ 2001; 1 female, Luiz Antônio, SP, Lagoa do Óleo, E. E. de Jataí. Leg. S. T. Strixino, 05/VIII/ 2003; 1 pupa with pharate female and larval exuviae, Lagoa do Diogo, E. E. de Jataí, Leg. L. C. Correia, 25/VII/2001. The holotype and most paratypes are deposited in the Laboratório de Entomologia Aquática collection, Universidade Federal de 

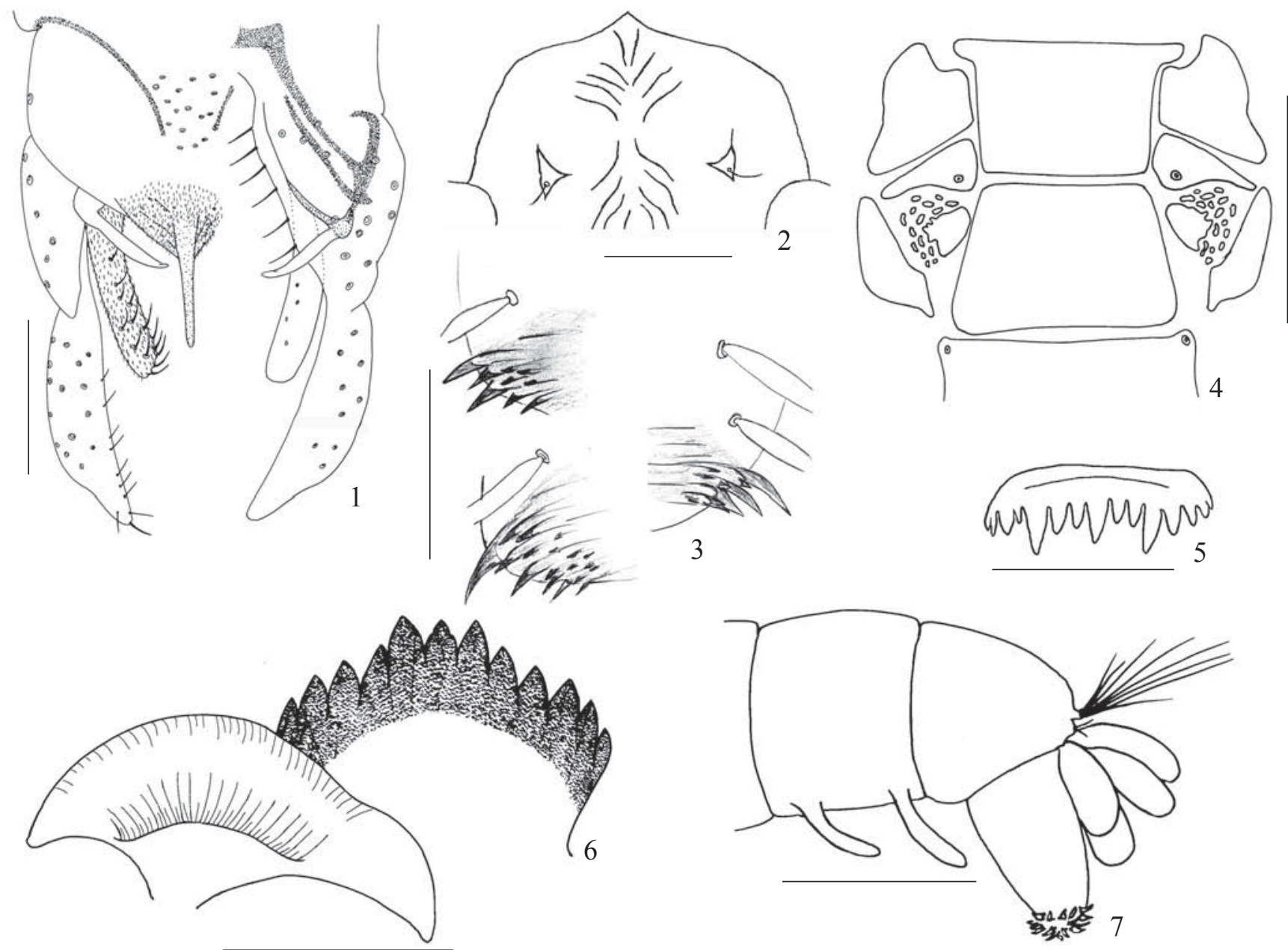

Figs. 1-7. Goeldichironomus luridus sp. nov. 1. Male hypopygium. 2. Pupal frontal apotome and cephalic tubercles. 3. Pupal anal comb variation. 4-7. Larva. 4. Frontal apotome and labral sclerites. 5. Pecten epipharyngis. 6. Mentum and ventromental plate. 7. Posterior abdominal segments. Scale: fig. $5=25 \mu \mathrm{m} ; 7=500 \mu \mathrm{m}$; others $=100 \mu \mathrm{m}$.

São Carlos, SP, Brazil (UFSCar). One male paratype is deposited in the Museu de Zoologia, USP, SP, Brazil.

Diagnosis. The male hypopygium of Goeldichironomus petiolicola sp. nov. differs from all other Goeldichironomus species by the shape of the gonostylus. The female genitalia of G. petiolicola differ from those of G. luridus sp. nov., G. holoprasinus (Goeldi) and G. amazonicus (Fittkau) by the shape of the postgenital plate and the number of setae on segment $X$ and on Gc IX. The following combined characteristics distinguish the $4^{\text {th }}$ instar larvae of $G$. petiolicola: consolidated labral sclerites 3 and 4 , short ventral tubules and the granulose surface of the pecten epipharyngis.

\section{Description}

Adult male.

Total length $5.84 \mathrm{~mm}$ (4.68 - 6.29). Color brownish yellow.

Head. Frontal tubercles slightly wider than high, about 9 $\mu \mathrm{m}$ long. Antenna $1.67 \mathrm{~mm}$ long $(1.46,1.69) ; \mathrm{AR}=2.72$ (2.24, 2.90). Palpomeres ${ }_{2-5}=44,112,137,162 \mu \mathrm{m}(50,62 ; 118,131 ; 118$, $156 ; 137,193)$. Clypeus with 17 setae $(14,17)$.

Thorax setal count: 15-17 acrostichals, 7-9 dorsocentrals, 4-7 prealars, 1 supraalar and 7-8 scutellars.
Wing. Length $2.80 \mathrm{~mm}(2.03,2.97)$, width $0.78 \mathrm{~mm}(0.51$, $0.92)$, membrane transparent, without setae. $R, R_{1}$ and $R_{4+5}$ setose. $\mathrm{VR}=1.13(1.08,1.10)$. Squama with $10-12$ long setae.

Legs. Fore femur yellowish; the other segments brownish. Femur, tibia and tarsomeres 1 and 2 of mid and hind legs yellowish, other tarsomeres brownish.

Segment lengths in $\mu \mathrm{m}$ and LR:

\begin{tabular}{lllll}
\hline & $\mathrm{Fe}$ & $\mathrm{Ti}$ & $\mathrm{Ta}_{1}$ & $\mathrm{Ta}_{2}$ \\
\hline $\mathrm{I}$ & 1338 & 1015 & 1615 & 830 \\
$\mathrm{II}$ & 923,1292 & 1046,1061 &,,- 1692 &,- 861 \\
& 1185 & 1061 & 585 & 338 \\
$\mathrm{III}$ & 1000,1246 & 969,1123 & 461,554 & 277,369 \\
& 1354 & 1538 & 1046 & 477 \\
& 1138,1461 & 1292,1631 &,- 969 &,- 538 \\
\hline & $\mathrm{Ta}_{3}$ & $\mathrm{Ta}_{4}$ & $\mathrm{Ta}_{5}$ & $\mathrm{LR}$ \\
\hline & 692 & 461 & 261 & 1.59 \\
&,- 769 &,- 615 &,- 292 &,- 1.59 \\
& 276 & 185 & 120 & 0.55 \\
& 261,277 & 154,200 & 108,154 & $0.47,0.49$ \\
& 431 & 308 & 185 & 0.68 \\
&,- 461 &,- 292 &,- 200 &,- 0.59 \\
\hline
\end{tabular}



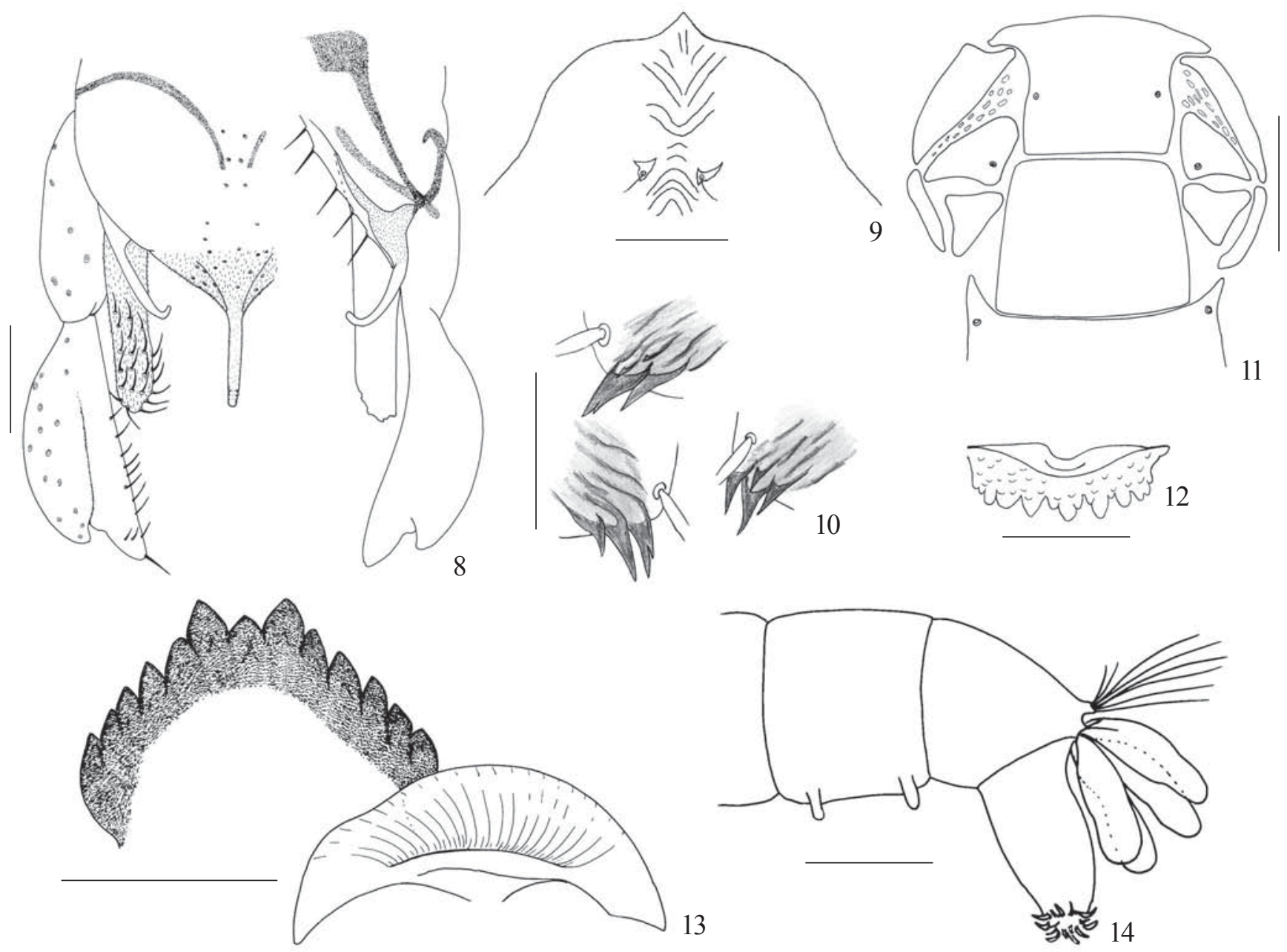

Figs 8-14. Goeldichironomus petiolicola sp. nov. 8. Male hypopygium. 9. Pupal frontal apotome and cephalic tubercles. 10. Pupal anal comb variation. 11-14. Larva. 11. Frontal apotome and labral sclerites. 12. Pecten epipharyngis. 13. Mentum and ventromental plate. 14. Posterior abdominal segments. Scale: fig. $12=25 \mu \mathrm{m} ; 14=500 \mu \mathrm{m}$; others $=100 \mu \mathrm{m}$.

Hypopygium (Fig. 8). Anal point slender, apex with short folds, slightly bent to ventral. Superior volsella strongly hooklike. Inferior volsella more or less parallel-sided and not clubbed apically, bearing 20-22 long setae. Gonostylus broad, with a mid-lateral protuberance that is distally separated from the gonostylus apex by a distinct invagination.

Adult female. Total length $5.4 \mathrm{~mm}$. Coloration as male.

Head. Frontal tubercles about $10 \mu \mathrm{m}$ long. Antennal flagellomeres ${ }_{1-5}=144,119,123,123,238 \mu \mathrm{m}$. AR $=0.29$. Palpomeres $_{2-5}=43,119,144,175 \mu \mathrm{m}$. Clypeus with 20 setae.

Thoracic setal count: 15 acrostichals, 10 dorsocentrals, 5 prealars, 1 supraalar, 7 scutellars.

Wing. Length $2.95 \mathrm{~mm}$, width $0.95 \mathrm{~mm}$. VR $=1.24$.

Leg segment lengths in $\mu \mathrm{m}$ and LR:

\begin{tabular}{lllllllll}
\hline & $\mathrm{Fe}$ & $\mathrm{Ti}$ & $\mathrm{Ta}_{1}$ & $\mathrm{Ta}_{2}$ & $\mathrm{Ta}_{3}$ & $\mathrm{Ta}_{4}$ & $\mathrm{Ta}_{5}$ & $\mathrm{LR}$ \\
\hline I & 1307 & 1000 & 1569 & 831 & 738 & 615 & 307 & 1.57 \\
II & 1092 & 1077 & 615 & 323 & 246 & 185 & 154 & 0.57 \\
III & 1308 & 1569 & 861 & $5-7$ & 400 & 261 & 200 & 0.54 \\
\hline
\end{tabular}

Genitalia. Sternite VIII bearing more than 60 irregularly distributed setae on each side. Seminal capsule ovoid, about $180 \mu \mathrm{m}$ long, with short neck. Spermathecal duct straight. Gc IX with 1-2 setae. Segment $X$ with 11-12 setae on each side. Postgenital plate triangular, pointed at apex.

Pupa.

Exuviae grayish. Abdomen length $5.0 \mathrm{~mm}$. Cephalic tubercles very short; frontal setae inserted subapically (Fig. 9). Hook row $590 \mu \mathrm{m}$ long, about $3 / 4$ width of segment II. Pedes spurii B present on segment II. Pedes spurii A present on sternite IV. Posterolateral corners of paratergites V-VII with patches of small spines. Sternites bare. Tergite I without shagreen, II-VI extensively covered with strong shagreenation, VII and VIII each with 2 anterior patches of fine shagreen. Segment VIII with posterolateral brownish anal comb of 2-3 marginal teeth and 2-4 short additional ventral teeth (Fig. 10). Anal lobe with complete fringe of ca 70-80 taeniae and 1 long dorsal taenia on each side. Abdominal setation: segments I $\mathrm{IV}=1,3,3,3 \mathrm{~L}$ setae; $\mathrm{V}$ - VIII = 4, 4, 4, 5 lateral taeniae.

$4^{\text {th }}$ instar larva.

Total length $8.20 \mathrm{~mm}$. Color red; head with dark brown 
ventral occipital margin and triangulum occipitale. Head: Width $550 \mu \mathrm{m}$, length $700 \mu \mathrm{m}$. Labral sclerites $1-5$ as in figure 11 . Premandible with 2 teeth. Pecten epipharyngis with granulose surface and 14-15 unequal distal teeth (fig. 12). Antennal segment lengths $=85,92 ; 31,40 ; 20,24 ; 18,24 ; 7,9 \mu \mathrm{m} ; \mathrm{AR}=1$. 09, 0.97. Mandible about $220 \mu \mathrm{m}$ long; pecten mandibularis well developed. Mentum (fig. 13) $175 \mu \mathrm{m}$ wide, with slightly notched median and 6 pair of dark lateral teeth; median tooth shorter than first laterals.

Abdomen (Fig. 14) with two pairs of very short ventral tubules on $8^{\text {th }}$ segment, measuring about $80 \mu \mathrm{m}$. Anal tubules about $350 \mu \mathrm{m}$.

\section{Ecological Notes}

The larvae of $G$. petiolicola live inside the petioles of emergent aquatic macrophytes, Eichhornia azurea and Pontederia lanceolata. Inside the plants, the larvae live in shelters, just below the leaf epidermis. These cases, not much larger than the length of their occupants, are open at both ends, and longitudinally lead into the leaf stalk.

Gut content analysis of some larvae revealed the presence of detritus mixed with algae and plant tissue remains. Thus, $G$. petiolicola should be included in the category of facultative phytophages described by Van der Veld \& Hiddinks (1987), in which larvae feed on seston and use the plant solely as a substratum for mining and filter feeding. According to Berg (1950), larvae of this category consume plant tissue incidentally when enlarging their burrows or excavating new ones.

\section{REFERENCES}

Berg, C. O. 1950. Biology of certain Chironomidae reared from Potamogeton. Ecological Monographs 20: 83-101.

Epler, J. H. 2001. Identification Manual for the larval
Chironomidae (Diptera) of North and South Carolina. North Carolina Department of Environment and Natural Resources Division of Water Quality, $528 \mathrm{pp}$.

Fittkau, E. J. 1968. Siolimyia amazonica n. gen. n. spec., eine flugfähige Chironomide (Diptera) mit einem Hypopygium inversum. Amazoniana 1: 259-265, 9 pls.

Langton, P. H. 1994. If not "filaments" then what? Chironomus 6: 9.

Grodhaus, G. 1967. Identification of chironomid midges commonly associated with waste stabilization lagoons in California. California Vector Views 14: 1-12.

Reiss, F. 1974. Die in stehenden Gewässern der Neotropis verbreitete Chironomidengattung Goeldichironomus Fittkau (Diptera, Insecta). Studies on Neotropical Fauna 9: 85-122.

Roque, F. O.; L. C. S. Correia; S. Trivinho-Strixino \& G. Strixino. 2004. A review of Chironomidae studies in lentic systems in the state of São Paulo, Brazil. Biota Neotropica 4: 20p.

Sæther, O. A. 1977. Female genitalia in Chironomidae and other Nematocera: morphology, phylogeny, keys. - Bulletin of the Fisheries Research Board of Canada 197: 1-209.

Saether, O. A. 1980. Glossary of chironomid morphology terminology (Diptera: Chironomidae). Entomologica scandinavica Supplement 14: $1-51$.

Spies, M. \& F. Reiss. 1996. Catalog and bibliography of Neotropical and Mexican Chironomidae (Insecta, Diptera). Spixiana Supplement 22: 61-119.

Strixino, S. T. \& G. Strixino. 1982. Ciclo de vida de Chironomus sancticaroli Strixino \& Strixino (Diptera, Chironomidae). Revista Brasileira de Entomologia 26: 183-189.

Trivinho-Strixino, S. \& G. Strixino. 1998. Goeldichironomus neopictus, a new species from the southeast of Brazil: description and bionomic information (Insecta, Diptera, Chironomidae). Spixiana 21: $271-278$.

Trivinho-Strixino, S. \& G. Strixino. 1999. Insetos dípteros quironomídeos. p.: 141-148. In: Ismael, D.; W. C. Valenti; T. Matsumura-Tundisi; O. Rocha (eds.). Biodiversidade do Estado de São Paulo, Brasil. Vol. 4: Invertebrados de Água doce. São Paulo: Programa BIOTA/ FAPESP.

Van der Veld, G. \& R. Hiddinks. 1987. Chironomidae mining in Nuphar lutea (L.) Sm (Nymphaeaceae). Entomologica scandinavica Supplement 29: 255-264. 